\title{
Differential expression of the urokinase receptor (CD87) in arthritic and normal synovial tissues
}

\author{
Zoltan Szekanecz, G Kenneth Haines, Alisa E Koch
}

\begin{abstract}
Aim-To determine whether the urokinase plasminogen activator receptor (uPAR; CD87) exhibits a possible pathogenic role in rheumatoid and osteoarthritis.

Methods-A semiquantitative, indirect immunoperoxidase histochemical analysis was performed on frozen synovial tissue sections. The recently characterised monoclonal antibody 10G7 recognising transfectants bearing u-PAR was used. Synovial tissue was obtained from 10 patients with rheumatoid arthritis, 10 patients with osteoarthritis, and four normal subjects.

Results-u-PAR was expressed on $70-90 \%$ of synovial tissue lining cells and subsynovial, interstitial macrophages from the arthritis patients, but only on a few myeloid cells from the normal subjects. It was also present on more endothelial cells from the rheumatoid and osteoarthritis patients, than from normal synovial tissue.

Conclusions-Plasminogen activators are important in joint destruction underlying arthritis. The up-regulated expression of u-PAR in diseased versus normal synovial tissue suggests a role for this antigen in the inflammatory and angiogenic mechanisms underlying rheumatoid and osteoarthritis.
\end{abstract}

(F Clin Pathol 1997;50:314-319)

Keywords: rheumatoid arthritis; osteoarthritis; urokinase receptor; CD87

Department of

Medicine,

Northwestern

University Medical

School, Chicago,

Illinois, USA

A E Koch

\section{Department of \\ Pathology}

G K Haines

Third Department of Medicine, University Medical School, Debrecen, Hungary Z Szekanecz

Correspondence to: Dr AE Koch, Northwestern University Medical School, Department of Medicine, 303 East Chicago Avenue, Ward Building 3-315, Chicago, IL 60611, USA.

Accepted for publication 11 December 1996

Rheumatoid arthritis is a chronic inflammatory disease characterised by the transendothelial ingress of leucocytes into synovial tissue that is rich in newly formed blood vessels. ${ }^{1-5}$ A regulatory network of inflammatory cells and mediators, as well as cellular adhesion molecules (CAMs) play an important role in the pathogenesis of rheumatoid arthritis. ${ }^{34}$ Angiogenesis is crucial for the perpetuation of leucocyte extravasation into the synovial tissue in rheumatoid arthritis. ${ }^{5}$ These elements have also been implicated, although to a lesser extent, in osteoarthritis, an essentially degenerative joint disease with inflammatory features. ${ }^{46}$

There is substantial data suggesting that the urokinase plasminogen activator (u-PA), which is highly involved in the proteolytic joint destruction underlying arthritis, interacts with a number of participants in the regulatory network described above. u-PA, a serine protease, activates a cascade of proteolysis, leading to extracellular matrix (ECM) degradation, and thus it is involved in cell adhesion, migration, and proteolysis underlying tumour invasion, inflammation, angiogenesis, and tissue remodelling. ${ }^{7-10}$ The 50 to $65 \mathrm{kD}$ u-PA receptor (u-PAR), which binds to the N-terminal end of $\mathrm{u}-\mathrm{PA}$ and localises u-PA at the cell surface, has recently been clustered as CD87. ${ }^{11-14} \mathrm{u}-\mathrm{PAR}$ is a monocyte activation antigen ${ }^{13}{ }^{15}$ that also plays a role during macrophage differentiation. ${ }^{16}$ There are some data available on the roles of $\mathrm{u}-\mathrm{PA}$ and $\mathrm{u}-\mathrm{PAR}$ in inflammatory conditions, including arthritis. Little $\mathrm{u}-\mathrm{PA}$ is produced by resting monocytes/macrophages, $T$ lymphocytes, endothelial cells, chondrocytes, and synoviocytes. However, the secretion of u-PA by these cells and the expression of u-PAR on monocytes and endothelia is highly up-regulated on the activation of these cells by a number of inflammatory and angiogenic mediators. ${ }^{17-26}$ u-PAR is a glycosyl-phosphatidylinositol (GPI) anchored protein, which forms a complex with the $\beta 2$ integrins on monocytes. ${ }^{27}{ }^{28}$ It also interacts with other CAMs and ECM components, such as $\beta 1$ and $\beta 3$ integrins, and vitronectin on the cell surface. ${ }^{26}{ }^{29-31}$ The co-capping of u-PAR with other CAMs on the cell surface, which involves cyclic AMP dependent and protein kinase $C$ dependent signalling, results in the induction of leucocyte adhesion and chemotaxis. ${ }^{262732} 33$ The increased production of u-PA by cytokine-stimulated endothelial cells and the up-regulated expression of u-PAR in association with integrins on leucocytes plays an important role in leucocyteendothelial interactions and angiogenesis underlying inflammation.

Some data are available on the abundant production of u-PA and u-PAR in rheumatoid arthritis. Increased levels of $\mathrm{u}-\mathrm{PA}$ and $\mathrm{u}-\mathrm{PAR}$ were detected in synovial tissue extracts from rheumatoid versus osteoarthritis patients. ${ }^{34}$ The concentration of $\mathrm{u}-\mathrm{PA}$ was also increased in synovial fluids from rheumatoid versus osteoarthritis patients. ${ }^{35}$ In a preliminary study, most myeloid, and some endothelial cells in the synovial tissue from rheumatoid and osteoarthritis patients showed immunoreactivity with the 10G7 monoclonal antibody (MoAb). ${ }^{37}$ This $M o A b$ was later found to recognise transfectants bearing u-PAR. Descriptive immunohistochemistry performed by others revealed strong expression of u-PA and u-PAR in myeloid cells in the rheumatoid arthritis synovial tissue. ${ }^{34}{ }^{38}$ However, semiquantitative immunohistochemical analysis on synovial u-PAR has not yet been carried out, nor has the expression of u-PAR in normal synovial tissue 
been investigated. The present study used detailed semiquantitative immunohistochemistry to determine the distribution of u-PAR synovia from rheumatoid and osteoarthritis patients and normal subjects.

\section{Methods}

Synovial tissue was obtained from 10 rheumatoid and 10 osteoarthritis patients undergoing arthroplasty. The diagnosis of arthritis met the American College of Rheumatology criteria. ${ }^{39-41}$ Normal synovial tissue was dissected from fresh pathological specimens or at necropsy. Synovial tissue was snap frozen in OCT compound (Miles, Elkhart, Indiana, USA). All samples were obtained with Institutional Review Board approval.

An MoAb, 10G7, produced in our laboratory, was submitted to the myeloid panel of the Sixth International Workshop and Conference on Leukocyte Differentiation Antigens. Studies carried out for this workshop determined that this antibody reacted with transfectants bearing CD87, u-PAR (Sanna M Goyert, Robert F Todd III, personal communication). Another MoAb, L21, raised against the same antigen was submitted to the previous, fifth international workshop by Dr Boyle (Melbourne, Australia) and this was also used in a pilot study on synovial tissue from three rheumatoid and three osteoarthritis patients for comparison. Anti-factor VIII related antigen (MoAb FVIII; Dakopatts, Carpinteria, California, USA) was used to detect endothelial cells, and MoAb LeuM5 (Becton Dickinson, Mountain View, California, USA) recognising CD11c was used to identify macrophages. ${ }^{42}{ }^{43}$ Purified mouse IgG1 supplied by the fifth workshop was used as an isotype specific negative control. Indirect immunoperoxidase staining was performed as described previously ${ }^{44}$ using a Vector $\mathrm{ABC}$ assay system (Vector Laboratories, Burlingame, California, USA) and diaminobenzidine (Kirkegaard \& Perry, Gaithersburg, Maryland, USA) as a chromogen.

Cell types present in synovial tissue were identified by their morphology after haematoxylin counterstaining, and by using the aforementioned positive control MoAb. Synovial tissue samples were assigned scores for the number of macrophages, degree of inflammation, and the number of blood vessels on a relative scale of 1 to 3 , with 3 being the highest score (for example, a macrophage score of 1,2 , and 3 represented $<25,25-100$, and $>100$ macrophages per $\times 400$ microscopic field, respectively). Inflammatory and vessel scores were obtained similarly. The specific cell types evaluated in the synovial tissue were lining cells, subsynovial macrophages, fibroblasts, vascular endothelium, vascular smooth muscle, and lymphocytes. All immunostaining of synovial tissue components was graded by frequency on a scale of $0 \%$ to $100 \%$, where $0 \%$ indicated no staining and $100 \%$ showed that all cells were immunoreactive. Five $\times 400$ fields were examined per section. Data were pooled and the mean (SEM) was calculated for each data group. In addition, presence ("positive tissues" with $>10 \%$ immunoreactive cells) or absence ("negative tissues" with $<10 \%$ immunoreactive cells) of cellular immunoreactivity with MoAb 10G7 was also noted in each tissue. Specimens were analysed by one investigator (GKH) as a blinded observer and, in the case of selected synovial tissue samples, also by the other two investigators. In general, no major differences were found between the analysis of the three observers.

Corresponding data groups were compared using an independent $t$ test. In addition, all inflammatory, macrophage, and vessel scores, as well as synovial tissue lining, macrophage, and endothelial immunoreactivity values were pooled, regardless of whether they were obtained from rheumatoid arthritic, osteoarthritic or normal synovial tissue, resulting in a total of 24 values in each data group. A multiway Pearson correlation analysis was performed between any two of these data groups. $\mathrm{p}<0.05$ was considered significant.

\section{Results}

Synovial tissue from rheumatoid arthritis patients exhibited a significantly higher inflammatory score $(2.1(0.3))$, macrophage score $(2.3(0.3))$, and vessel score $(2.6(0.2))$ than tissue from patients with osteoarthritis (1.3 (0.1), $1.4(0.2), 1.9(0.1)$, respectively) or normal synovial tissue $(1(0), 1(0), 2(0)$, respectively) ( $\mathrm{p}<0.05$, rheumatoid arthritis versus osteoarthritis or normals). Significant correlations were found between inflammatory and macrophage scores $(r=0.76 ; \mathrm{p}<0.05)$, between inflammatory and vessel scores $(r=0.44 ; \mathrm{p}<0.05)$, and between macrophage and vessel scores $(r=0.57 ; \mathrm{p}<0.05)$ in rheumatoid arthritis, osteoarthritis and normal synovial tissue (data not shown).

u-PAR, recognised by the 10G7 MoAb, was present on the majority of synovial tissue lining cells and subsynovial macrophages from rheumatoid arthritis patients $(91 \%$ and $78 \%$ immunoreactive cells, respectively) and osteoarthritis patients ( $86 \%$ and $68 \%$, respectively). In contrast, significantly fewer lining cells ( $8 \%$ ) and macrophages $(23 \%)$ expressed $\mathrm{u}-\mathrm{PAR}$ in normal synovia ( $\mathrm{p}<0.05$ ) (figs 1 and 2 ).

When analysing the number of "positive" tissues, synovial tissue lining cells and macrophages showed immunoreactivity with MoAb $10 \mathrm{G} 7$ in almost all (90-100\%) samples from rheumatoid and osteoarthritis patients. In normal synovial tissue, lining and macrophages expressed u-PAR in only one of three $(33 \%)$ and one of four tissues (25\%), respectively (table 1).

u-PAR was also present on some endothelial cells from rheumatoid arthritis patients $35 \%$ immunoreactive cells), osteoarthritis patients (55\%), and normals (25\%) (figs 1 and 2 ). However, while some endothelial staining was observed in a number of synovial tissue sections from rheumatoid arthritis patients (six of 10) and osteoarthritis patients (eight of 10), endothelia from three of four normal synovial tissue sections expressed no u-PAR (an outlier $100 \%$ endothelial immunoreactivity was found in one of the normal sections) (table 1). 

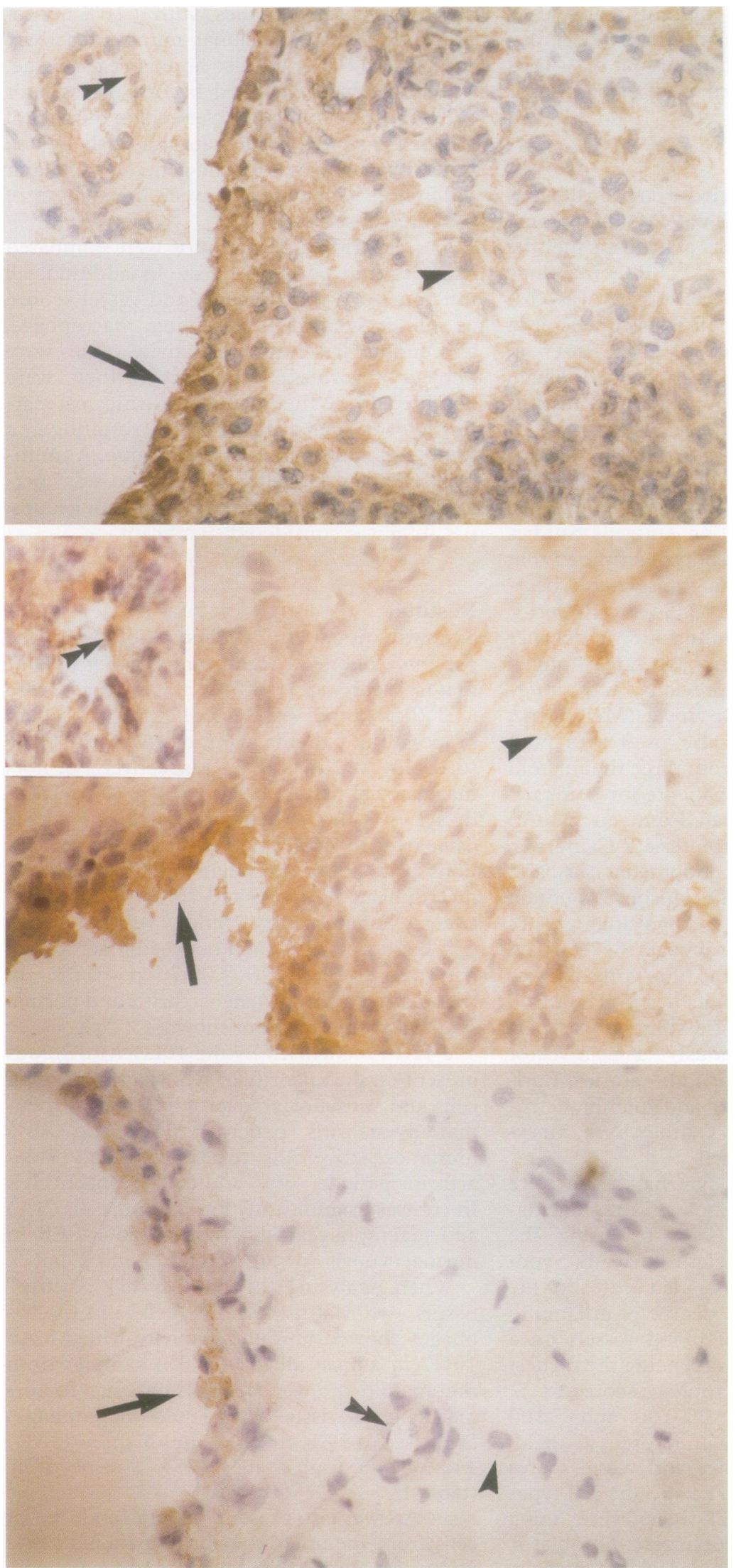

Figure 1 Indirect immunoperoxidase staining of frozen synovial tissue sections using $M o A b 10 G 7$ recognising the urokinase receptor (original magnification $\times 1056$ ). (Top) Rheumatoid arthritis, synovial tissue lining layer (arrow), interstitial macrophages (single arrowhead), and endothelial cells (insert, double arrowhead) showing u-PAR immunoreactivity. (Middle) Osteoarthritis, synoviai tissue lining layer (arrow), macrophage (arrowhead), and endothelial (insert, double arrowhead) reactivity. (Bottom) Normal synovial tissue showing very low immunostaining of lining layer (arrow). Macrophages (arrowhead) and endothelial cells (double arrowhead) are not reactive.
Table 1 Immunoreactivity of synovial tissue in patients with rheumatoid or osteoarthritis, and normal subjects with MoAb $10 G 7$ recognising urokinase plasminogen activator receptor

\begin{tabular}{llll}
\hline & Lining & Macrophages & Endothelium \\
\hline Rheumatoid arthritis & & & \\
$\quad(n=10)$ & $9^{\star}$ & 9 & 6 \\
Osteoarthritis $(n=10)$ & 10 & 10 & 8 \\
Normal subjects $(n=4)$ & $1^{\star}$ & 1 & 1 \\
\hline
\end{tabular}

Values indicate the number of "positive" tissues. Synovial tissue were considered "positive" if $10 \%$ or more cells showed immunoreactivity with MoAb 10G7.

*No synovial tissue lining was available in one rheumatoid arthritis and one normal sample.

In a pilot experiment, another MoAb (L21) was used to detect u-PAR in synovial tissue from three rheumatoid arthritis and three osteoarthritis patients. This MoAb reacted with $93-98 \%$ of lining cells, and $92-98 \%$ of subsynovial macrophages in both groups (data not shown).

When using MoAb 10G7, we found a positive correlation between $\mathrm{u}-\mathrm{PAR}$ reactivity in the synovial tissue lining layer versus subsynovial macrophages in samples from patients with rheumatoid and osteoarthritis, as well as in normal controls $(r=0.63, \mathrm{p}<0.05$; fig 3). u-PAR expression on synovial tissue lining cells also significantly correlated with inflammatory scores $(r=0.44 ; \mathrm{p}<0.05)$. These results suggest that $\mathrm{u}-\mathrm{PAR}$ is predominantly expressed by cells of myeloid origin, such as lining cells and macrophages from inflamed synovia.

\section{Discussion}

Leucocyte ingress into synovial tissue plays an important role in the pathogenesis of rheumatoid arthritis and, to a lesser extent, of osteoarthritis. ${ }^{1-36}$ Previous, mainly descriptive, immunohistochemical studies carried out by us and by others suggested that u-PAR is expressed by cells of myeloid origin, such as synovial tissue lining cells and interstitial macrophages in the synovial tissue from rheumatoid arthritis patients. ${ }^{34}{ }^{37}$ Higher levels of $\mathrm{u}-\mathrm{PA}$ were detected in the peripheral blood, synovial fluid samples, and synovial tissue extracts of rheumatoid versus osteoarthritis patients. ${ }^{34-36} 45$ The expression of u-PAR on peripheral blood monocytes was also increased in rheumatoid versus osteoarthritis and normal subjects. ${ }^{46}$ The present, semiquantitative immunohistochemical analysis with MoAb $10 \mathrm{G} 7$ found that most synovial tissue lining cells (86-91\%) and subsynovial macrophages (68-78\%) expressed $\mathrm{u}-\mathrm{PAR}$ in synovial tissue from both rheumatoid and osteoarthritis patients without major differences between the two diseases. In contrast, u-PAR was present on significantly fewer synovial tissue lining cells $(8 \%)$ and macrophages (23\%) in normal synovia. MoAb L2 1 also detected u-PAR on more than $90 \%$ of myeloid cells in both diseases. Ronday et al reported strong u-PAR expression in the synovial tissue lining layer from rheumatoid arthritis patients; however, it was barely detectable in the synovial tissue from osteoarthritis patients. ${ }^{34}$ This study did not evaluate the percentage of immunoreactive cells in any synovial 




Figure 2 Percentage reactivity of synovial tissue components with MoAb 10 G7 raised against $u-P A R$. Bars represent the mean (SEM). ${ }^{\star} P<0.05$ between groups. Lining, synovial tissue lining cell layer; macrophage, subsynovial (scattered) macrophages; endothelium, vascular endothelium; Smooth muscle, vascular smooth muscle.

tissue sample. ${ }^{34}$ We analysed the number of cells expressing u-PAR, but not the density of u-PAR expression on the cell surface. The number of u-PARs is increased in peripheral blood monocytes form rheumatoid arthritis patients compared with osteoarthritis patients and normal subjects. ${ }^{46}$ Therefore, although most myeloid cells express $\mathrm{u}-\mathrm{PAR}$ in tissues from both rheumatoid and osteoarthritis patients, the number of receptors on these cells may be much lower in synovial tissue from osteoarthritis patients resulting in possible differences in sensitivity between that study and ours. Alternatively, tissue from osteoarthritis patients included in our study may be more inflamed that the ones used by the other group. However, we have also reported that another GPI linked myeloid antigen, CD66, was also up-regulated on synovial tissue lining cells and macrophages in rheumatoid and osteoarthritis versus normal synovia. ${ }^{47}$

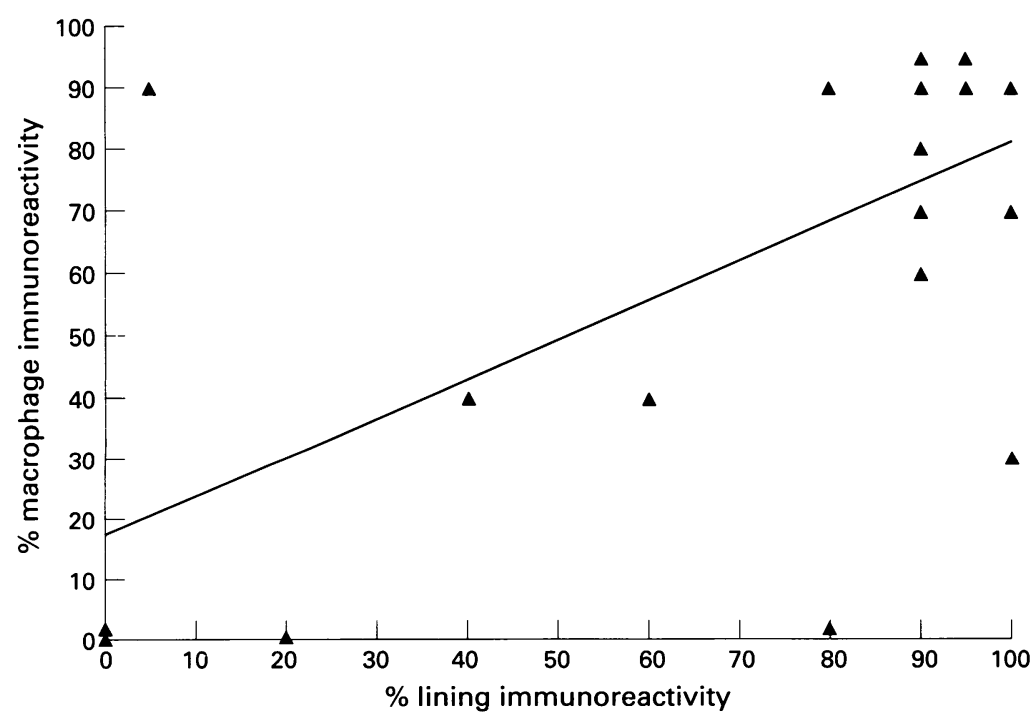

Figure 3 Correlation between $u-P A R$ expression in synovial tissue lining cells versus subsynovial macrophages determined using MoAb 10 G 7 from 23 patients. $(r=0.63$; P<0.05).
Plasminogen activators, such as u-PA, may modulate synovial inflammation, angiogenesis, and joint destruction in a number of ways. u-PA may be involved in the recruitment of inflammatory leucocytes into the synovial tissue, as it is chemotactic for neutrophils ${ }^{48}$ and it stimulates cytokine dependent monocyte adhesion. ${ }^{33} \mathrm{u}$-PAR has been identinied as the monocyte activation antigen $\mathrm{Mo}-3,{ }^{15}$ and its soluble form has been detected in the conditioned media of activated monocytes. ${ }^{13}$ u-PAR is involved in macrophage differentiation, monocyte derived pericellular proteolysis, adhesion to the ECM, and the stimulation of metalloproteinase production. ${ }^{16}$

$\mathrm{u}-\mathrm{PA}$ is also a potent mediator of angiogenesis. ${ }^{10}$ Cytokine stimulated endothelia produce high amounts of u-PA that, in turn, enables ECM degradation, endothelial cell migration, and vessel formation. ${ }^{20} 4950$ u-PA acts by inducing plasmin dependent release of the angiogenic basic fibroblast growth factor (bFGF) from the ECM. ${ }^{18}$ u-PAR antagonists block neovascularisation in vitro. ${ }^{49}$

u-PA and its receptor interact with other inflammatory mediators in arthritic synovial tissue. Unstimulated monocytes/macrophages, $T$ cells, endothelial cells, chondrocytes, and synoviocytes produce low amounts of u-PA. ${ }^{21} 23$ Inflammatory mediators, such as interleukin (IL)-1 $\beta$, tumour necrosis factor (TNF)- $\alpha$, transforming growth factor- $\beta$, and granulocyte-monocyte colony stimulating factor, enhance u-PA secretion by most of these cell types. ${ }^{17-24}$ TNF- $\alpha$, interferon (IFN) $\gamma$ and bFGF induce u-PAR expression on monocytes. ${ }^{25}$ u-PA itself can increase the number of u-PARs on monocytes, resulting in the perpetuation of inflammation, proteolysis and angiogenesis. ${ }^{25}$ Most of these cytokines as well as u-PA are present in high quantities, and play an important role in the synovial tissue of rheumatoid and osteoarthritis patients. ${ }^{4634}$ In the present study, we also detected strong $\mathrm{u}-\mathrm{PAR}$ expression on cells of myeloid origin, as well as on some endothelial cells in the majority of the inflamed, but not in normal, synovial tissue.

$\mathrm{u}-\mathrm{PAR}$ acts in close association with CAMs and ECM components during the adhesion of monocytes and endothelial cells. It forms a complex with the CDllb/CD18 $\beta 2$ integrin, which facilitates integrin dependent adhesive functions. ${ }^{28}$ However, co-clustering of the antigen receptor complex with $\beta 1$ and $\beta 2$ integrins induce u-PAR expression on T cells. ${ }^{26} \mathrm{u}$-PAR serves as a receptor for vitronectin on endothelia, and adhesion to this ECM molecule results in clustering of u-PAR on the endothelial surface, as well as increased u-PA production. ${ }^{30}{ }^{31}$ Blocking the vitronectin receptor. $\alpha \mathrm{V} / \beta 3$ integrin results in a decrease in $\mathrm{u}-\mathrm{PAR}$ mRNA expression suggesting that $\alpha \mathrm{V} / \beta 3$ and $\mathrm{u}-\mathrm{PAR}$ act in concert during adhesion to vitronectin. ${ }^{29}$ The co-capping of u-PAR with other CAMs on the cell surface results in antigen clustering, which regulates focal adhesion, signalling, and pericellular u-PA activities. ${ }^{916} 31-3351$ 
u-PAR and u-PA may have significant clinical, both diagnostic (prognostic) and therapeutic, relevance. For example, the expression of u-PA correlates with survival in breast cancer. ${ }^{52}$ u-PAR expression is upregulated on brain microvascular endothelia in multiple sclerosis compared with healthy subjects. ${ }^{53} \mathrm{u}-\mathrm{PAR}$ antagonists have been shown to inhibit angiogenesis and tumour growth in syngeneic mice in vivo, ${ }^{8}$ as well as endothelial cell migration and deformability in vitro. ${ }^{49}$ Anti-angiogenic factors, such as IFN- $\alpha$, angiostatic steroids, and suramin down regulate $\mathrm{u}-\mathrm{PA}$ production and activities. ${ }^{54}$

Both u-PA and u-PAR deficient mice have been generated and characterised. These animals showed impaired plasminogen activating potential and inflammatory responses. ${ }^{55} 56$ Tenoxicam, a non-steroidal anti-inflammatory drug used in the treatment of arthritis, down-regulated u-PAR expression on monocytes. ${ }^{57}$ Urinary trypsin inhibitor, which blocks u-PA production, also relieved arthritic symptoms in rheumatoid arthritis patients. ${ }^{36}$ Thus, the suppression of $\mathrm{u}-\mathrm{PA}$ production and u-PAR expression using antagonists, antibodies, or antisense oligonucleotides may be useful for the management of inflammatory diseases, including rheumatoid and osteoarthritis. $^{78294954}$

Addendum: Additional data obtained from the Sixth International Workshop and Conference on Leukocyte Differentiation Antigens indicated that on the basis of its selective binding to a u-PAR transfectant, MoAb 10G7 may recognise a CD87 epitope, but its reactivity remains to be confirmed by alternate methodology (Todd RF, personal communication).

We thank our colleagues Drs G Rayan, SD Stulberg, C Schwartz, J Galante, B Briggs, N Rana, LA Pottenger, A Rosenberg, and J Lessard for supplying the synovial tissues. Preliminary results were presented as part of the Fifth International Workshop on Human Leukocyte Differentiatio Antigens, Kobe, Japan, 1996. This work was supported by NIH grants AR30692 and AR41492 (AEK), funds from the grants AR30692 and AR41492 (AEK), funds from the Ralph and Marion Falk Challenge Prize of the Arthritis FounRalph and Marion Falk Challenge Prize of the Arthritis Fountion grant No T013239 (ZS), and Hungarian Medical Research tion grant No T013239 (ZS), and
Council grant No $156 / 93$ (ZS).

1 Jalkanen S. Leukocyte-endothelial cell interaction and the control of leukocyte migration into inflamed synovium. Springer Semin Immunopathol 1989;11:187-98.

2 Haynes BF, Hale LP, Denning SM, Le PT, Singer KH. The role of leukocyte adhesion molecules in cellular role of leukocyte adhesion molecules in cellular interactions: implications for the pathogenesis of inflammatory

3 Szekanecz Z, Szegedi G, Koch AK. Cellular adhesion molecules in rheumatoid arthritis: regulation by cytokines an possible clinical importance. F Invest Med 1996;44:124-35.

4 Koch AK, Kunkel SL, Strieter RM. Cytokines in rheumatoid arthritis. F Invest Med 1995;43:28-38.

5 Colville-Nash PR, Scott DL. Angiogenesis and rheumatoid arthritis: pathogenic and therapeutic implications. $A n$ Rheum Dis 1992;51:919-25.

6 Westacott CI, Sharif M. Cytokines in osteoarthritis: mediators or markers of joint destruction. Semin Arthritis Rheum 1996;25:254-72.

7 Schmitt M, Wilhelm O, Janicke F, Magdolen V, Reuning U, Ohi $\mathrm{H}$, et al. Urokinase type plasminogen activator (uPA) and its receptor (CD87): a new target in tumor invasion and metastasis. F Obstet Gynecol 1995;21:151-65.

8 Min HY, Doyle LV, Vitt CR, Zandonella CL, StrattonThomas JR, Shuman MA, et al. Urokinase receptor antagonists inhibit angiogenesis and primary tumor growth in syngeneic mice. Cancer Res 1996;56:2428-33.

9 Blasi F. Urokinase and urokinase receptor: a paracrine/ autocrine system regulating cell migration and invasiveness. Bioessays 1993;15:105-11.
10 Goldfarb RH, Ziche M, Murano G, Liotta LA. Plasminogen activators (urokinase) mediate neovascularization: possible role in tumor angiogenesis. Semin Thromb Hemost 1986;12 $337-8$.

11 Todd RF III, Barnathan ES, Bohuslav J, Chapman HA Cohen RL, Felez J, et al. CD87 cluster workshop report. In Schlossman SF, Boumsell L, Gilks W, Harlan JM Kishimoto T, Morimoto C, et al, eds. Leukocyte typing $V$. White cell differentiation antigens, Vol 1. Oxford: Oxford University Press, 1995:932-9.

12 Magdolen V, Rettenberger P, Koppitz M, Goretzki L, Kessler H, Weidle UH, et al. Systematic mutational analysis of the receptor-binding region of the human urokinasetype plasminogen activator. Eur $\mathcal{F}$ Biochem 1996;237:74351 .

13 Mizukami IF, Faulkner NE, Gyetko MR, Sitrin RG, Todd RF III. Enzyme-linked immunoabsorbent assay detection of a soluble form of urokinase plasminogen activator receptor in vivo. Blood 1995;86:203-11.

14 Roldan AL, Cubellis MV, Masucci MT, Behrendt N, Lund $\mathrm{LR}, \mathrm{Dano}, \mathrm{K}$, et al. Cloning and expression of the recepto for human urokinase plasminogen activator, a central molecule in cell surface, plasmin-dependent proteolysis. $E M B O$ f 1990;9:467-74.

15 Min HY, Semnani R, Mizukami IF, Watt K, Todd RF, Liu DY. cDNA for Mo3, a monocyte activation antigen, encodes the human receptor for urokinase plasminogen activator. F Immunol 1992;148:3632-42.

16 Rao NK, Shi GP, Chapman HA. Urokinase receptor is a multifunctional protein: influence of receptor occupancy on macrophage gene expression. $\mathcal{F}$ Clin Invest 1995;96:46574.

17 Hamilton JA, Piccoli DS, Leizer T, Butler DM, Croatto M Royston AK. Transforming growth factor beta stimulates urokinase-type plasminogen activator and DNA synthesis, but not prostaglandin E2 production, in human synovia fibroblasts. Proc Natl Acad Sci USA 1991;88:7180-4.

18 Falcone DJ, McCaffrey TA, Haimovitz-Friedman A, Garcia $M$. Transforming growth factor-beta 1 stimulates macrophage urokinase expression and release of matrix-bound basic fibroblast growth factor. F Cell Physiol 1993;155:595605 .

19 Mignatti P, Mazzieri R, Rifkin DB. Expression of the urokinase receptor in vascular endothelial cells is stimulated by basic fibroblast growth factor. $\mathcal{F}$ Cell Biol 1991;113:1193201

20 Niedbala $M J$, Stein $M$. Tumor necrosis factor induction of urokinase-type plasminogen activator in human endothelia cells. Biomed Biochim Acta 1991;50:427-36.

21 Hamilton JA, Hart PH, Leizer T, Vitti GF, Campbell IK. Regulation of plasminogen activator activity in arthritic joints. $¥$ Rheumatol $1991 ; 27$ (suppl): 106-9.

22 Pepper MS, Belin D, Montesano R, Orci L, Vassalli JD. Transforming growth factor-beta 1 modulates basic fibroblast growth factor-induced proteolytic and angiogenic last growth factor-induced proteolytic and angiogenic
properties of endothelial cells in vitro. $7 \mathrm{Cell} \mathrm{Biol} \mathrm{1990;111:}$ properties

23 van Hinsbergh VW, van den Berg EA, Fiers W, Dooijewaard G. Tumor necrosis factor induces the production of urokinase-type plasminogen activator by human endothelial cells. Blood 1990;75:1991-8.

24 Campbell IK, Piccoli DS, Roberts MI, Muirden KD, Hamilton JA. Effects of tumor necrosis factor alpha and beta on resorption of human articular cartilage and production of plasminogen activator by human articular chondrocytes. Arthritis Rheum 1990;33:542-52.

25 Kirchheimer JC, Nong YH, Remold HG. IFN-gamma, tumor necrosis factor-alpha, and urokinase regulate the tumor necrosis factor-alpha, and urokinase regulate the
expression of urokinase receptors on human monocytes. Immunol 1988:141:4229-34.

26 Bianchi E, Ferrero E, Fazioli F, Mangili F, Wang J, Bende $\mathrm{JR}$, et al. Integrin-dependent induction of functional urokinase receptors in primary $\mathrm{T}$ lymphocytes. 7 Clin Inves 1996;98:1133-41.

27 Bohuslav J, Horejsi V, Hansmann C, Stockl J, Weidle UH, Majdic O, et al. Urokinase plasminogen activator receptor, beta 2 -integrins, and Src-kinases within a single receptor complex of human monocytes. F Exp Med 1995;181:138190.

28 Sitrin RG, Todd RF III, Petty HR, Brock TG, Shollenberge $\mathrm{SB}$, Albrecht $\mathrm{E}$, et al. The urokinase receptor (CD87) facilitates $C D 11 \mathrm{~b} / \mathrm{CD} 18$-mediated adhesion of human monocytes. F Clin Invest 1996;97:1942-51.

29 Nip J, Rabbani SA, Shibata HR, Brodt P. Coordinated expression of the vitronectin receptor and the urokinasetype plasminogen activator receptor in metastatic melanoma cells. $\mathcal{F}$ Clin Invest 1995;95:2096-103.

30 Wei Y, Waltz DA, Rao N, Drummond RJ, Rosenberg S, Chapman HA. Identification of the urokinase receptor as an adhesion receptor for vitronectin. $₹ \mathrm{Biol}$ Chem 1994;269:32380-8.

31 Ciambrone GJ, McKeown-Longo PJ. Vitronectin regulates the synthesis and localization of urokinase-type plasminogen activator in HT-1080 cells. $\mathcal{F}$ Biol Chem 1992;267: gen activat

32 Langer DJ, Kuo A, Kariko K, Ahuja M, Klugherz BD, Ivanics KM, et al. Regulation of the endothelial cell urokinasetype plasminogen activator receptor. Evidence for cyclic AMPe plasminogen activator receptor. Evidence for cyclic AMP-dependent and protein
ways. Circ Res 1993;72:330-40.

33 Waltz DA, Sailor LZ, Chapman HA. Cytokines induce urokinase-dependent adhesion of human myeloid cells. A regulatory role for plasminogen activator inhibitors. $f$ Clin Invest 1993;91:1541-52. 
34 Ronday HK, Smits HH, Van Muijen GN, Pruszczynski MS, Dolhain RJ, Van Langelaan EJ, et al. Difference in expression of the plasminogen activation system in synovial tissue sion of the plasminogen activation system in synovial tissue of patients with rheumatoid arthri $1996 ; 35: 416-23$.

35 Saxne T, Lecander I, Geborek P. Plasminogen activators and plasminogen activator inhibitors in synovial fluid. Difference between inflammatory joint disorders and osteoarthritis. F Rheumatol 1993;20:91-6.

36 Kikuchi H, Tanaka S, Matsuo O. Plasminogen activator in synovial fluid from patients with rheumatoid arthritis. $\mathcal{F}$ Rheumatol 1987;14:439-45.

37 Koch AE, Szekanecz Z, Haines GK, Harlow LA, Shah MR, Fong $\mathrm{T}$, et al. Immunohistochemical characterization of myeloid antigens in arthritic and normal synovial tissues. In: Schlossman SF, Boumsell L, Gilks W, Harlan JM, Kishimoto T, Morimoto C, et al, eds. Leukocyte typing $V$ White cell differentiation antigens, Vol 1. Oxford: Oxford White cell differentiation antigens,

38 Zacharski LR, Brown FE, Memoli VA, Kisiel W, Kudryk BJ, Rousseau SM, et al. Pathways of coagulation activation in situ in rheumatoid synovial tissue. Clin Immunol Immun opathol 1992;63:155-62.

39 Arnett FC, Edworthy SM, Bloch DA, McShane DJ, Fries JF, Cooper NS, et al. The American Rheumatism Association 1987 revised criteria for the classification of rheumatoid arthritis. Arthritis Rheum 1988;31:315-24.

40 Altman R, Asch E, Bloch D, Bole G, Borenstein D, Brandt $\mathrm{K}$, et al. Development of criteria for the classification and reporting of osteoarthritis: classification of osteoarthritis of the knee. Arthritis Rheum 1986;29:1039-49.

41 Altman R, Alarcón G, Appelrouth D, Bloch D, Borenstein $\mathrm{D}$, Brandt $\mathrm{K}$, et al. The American College of Rheumatology $\mathrm{D}$, Brandt $\mathrm{K}$, et al. The American College of Rheumatology criteria for the classification and reporting of

42 Koch AE, Burrows JC, Haines GK, Carlos TM, Harlan JM Leibovich SJ. Immunolocalization of endothelial and leukocyte adhesion molecules in human rheumatoid and osteoarthritic synovial tissues. Lab Invest 1991;64:313-20.

43 Szekanecz Z, Haines GK, Lin TR, Harlow LA, Goerdt S, Rayan G, et al. Differential distribution of ICAM-1, ICAM-2 and ICAM-3, and the MS- 1 antigen in norma and diseased human synovia. Arthritis Rheum 1994;37: 221-31.

44 Hsu SM, Raine L, Fanger H. Use of avidin-biotin peroxidase complex (ABC) in immunoperoxidase peroxidase complex (ABC) in immunoperoxidase techniques: a comparison between $\mathrm{ABC}$ and unlabeled antibody (PAP) procedures. F Histochem Cytochem 1981;29: $577-80$.

45 Brommer EJ, Dooijewaard G. Dijkmans BA, Breedveld FC.
Depression of tissue-type plasminogen activator and enhancement of urokinase-type plasminogen activator as enhancement of urokinase-type plasminogen activator as
an expression of local inflammation. Thrombosis Haemost an expression

46 Kirchheimer JC, Remold HG, Wanivenhaus A, Binder BR Increased proteolytic activity on the surface of monocytes from patients with rheumatoid arthritis. Arthritis Rheum 1991;34:1430-3

47 Szekanecz Z, Haines GK, Harlow LA, Shah MR, Fong TW Fu R, et al. Increased synovial expression of the adhesion molecules CD66a, CD66b and CD31 in rheumatoid and osteoarthritis. Clin Immunol Immunopathol 1995;76:180-6.

48 Boyle MD, Chiodo VA, Lawman MJ, Gee AP, Young M. Urokinase: a chemotactic factor for polymorphonuclear leukocytes in vivo. 7 Immunol 1987;139:169-74.

49 Lu H, Mabilat C, Yeh P, Guitton JD, Li H, Pouchelet M, et al. Blockage of urokinase receptor reduces in vitro the al. Blockage of urokinase receptor reduces in vitro the Lett 1996;380:21-4.

50 Gerritsen ME, Niedbala MJ, Szczepanski A, Carley WW. Cytokine activation of human macro- and microvesselderived endothelial cells. Blood Cells 1993;19:325-9.

51 Mizukami IF, Garni-Wagner BA, DeAngelo LM, Lieber $\mathrm{M}$, Flint A, Lawrence DA, et al. Immunologic detection of the cellular receptor for urokinase plasminogen activator Clin Immunol Immunopathol 1994;71:96-104.

52 Hildenbrand R, Dilger I, Horlin A, Stutte HJ. Urokinase and macrophages in tumour angiogenesis. $\mathrm{Br} \mathcal{F}$ Cancer 1995;72:818-23.

53 Dore-Duffy P, Washington R, Dragovic L. Expression of endothelial cell activation antigens in microvessels from endothelial cell activation antigens in microvessels from patients with mul.

54 Pepper MS, Vassalli JD, Wilks JW, Schweigerer L, Orci L, Montesano R. Modulation of bovine microvascular en dothelial cell proteolytic properties by inhibitors of angiogenesis. F Cell Biochem 1994;55:419-34.

55 Gyetko MR, Chen GH, McDonald RA, Goodman R, Huffnagle GB, Wilkinson CC, et al. Urokinase is required for the pulmonary inflammatory response to Cryptococcus neoformans. A murine transgenic model. $\mathcal{f}$ Clin Invest 1996;97:1818-26.

56 Dewerchin M, Van Nuffelen A, Wallays G, Bouché A, Moons L, Carmeliet P, et al. Generation and characterization of urokinase receptor-deficient mice. $\mathcal{f}$ Clin Invest 1996;97:870-8.

57 Kirchheimer JC. Modulation of receptor bound urokinasetype plasminogen activator on human monocytes by non-steroidal antiinflammatory drugs. Scand $\mathcal{f}$ Rheumatol 1993;22:53-7. 